\title{
Arab others at European borders: racializing religion and refugees along the Balkan Route
}

\section{Piro Rexhepi}

To cite this article: Piro Rexhepi (2018) Arab others at European borders: racializing religion and refugees along the Balkan Route, Ethnic and Racial Studies, 41:12, 2215-2234, DOI: 10.1080/01419870.2017.1415455

To link to this article: https://doi.org/10.1080/01419870.2017.1415455
(c) 2018 The Author(s). Published by Informa UK Limited, trading as Taylor \& Francis Group

曲 Published online: 11 Jan 2018.

\section{Submit your article to this journal $\pi$}

\section{Џll Article views: 1138}

View Crossmark data 


\title{
Arab others at European borders: racializing religion and refugees along the Balkan Route
}

\author{
Piro Rexhepi
}

Max Planck Institute for the Study of Religious and Ethnic Diversity, Göttingen, Germany

\begin{abstract}
Engaging with critical border literature, this article examines how racial and religious categories are mobilized in materializing EU borders in the Balkans. Exploring the tensions that emerge in Muslim communities in post-Socialist and post-conflict Macedonia during the Syrian "refugee crisis" in 2015, it looks at how racialized categorizations of difference are deployed along the Balkan Route to differentiate local, white European Muslims from refugee Arab Others. Through policy analysis and fieldwork, the article questions the standard, colour-blind and equal-to-all European integration by highlighting political divisions that emerge within Muslim communities. While these tensions were present long before the ongoing refugee crisis, this article argues that the current geopolitical context allows for these tensions to be utilized in the surveillance and securitization of EU border regimes.
\end{abstract}

ARTICLE HISTORY Received 9 July 2016; Accepted 6 December 2017

KEYWORDS Balkans; borders; EU enlargement; Islam; Macedonia; refugees

\section{Introduction}

In summer 2015, I was conducting archival research and ethnographic fieldwork in Sofia, Skopje, Sarajevo and Tirana for a project on Islamic practices and politics during socialism. However, my attention was drawn to the more pressing problem of the refugee crisis. Visiting family in my native Prespa in southern Macedonia, on several occasions, I had seen refugees walking and biking north on European route E75, a 5,639-km-long highway stretching from Greece to Norway. As the Macedonian government had prevented their use of public transport, those who could afford to buy bikes cycled, while others walked, almost all of them transiting through Macedonia on their way to the north. The scenes were reminiscent of the 1999 Kosovo refugee crisis. Several local humanitarian organizations had emerged assisting 
with food, transportation and temporary shelter for the most vulnerable refugees. The response of local Muslim community initiatives and organizations was impressive. LEGIS, a humanitarian organization, took on the lead in organizing transportation, food, medical supplies and shelter for refugees. The Muslim community in Kumanovo, where refugees transited through on their way north into Serbia, opened the doors of the historic Sinan Tatar Pasha mosque to host and care for the refugees. In contrast, the response of state institutions and the state-sanctioned Islamic Religious Community of Macedonia (IRCM) was lukewarm at best. The head of the IRCM, Sulejman Rexhepi, visited several refugee centres and the IRCM organized food and clothing drives in Skopje and Gevgelija (the primary refugee entry point from Greece) while advising the members of the Muslim community to be cautious and keep a distance from the refugees. For instance, the IRCM questioned the arrival of several contingents of refugees on 10 June 2015 in the city of Kumanovo arguing that their accommodation in the mosques of the city and surrounding villages was a coordinated provocation, without specifically stating what that provocation might be (Laçi 2015).

This article explores the discrepancy between the reactions of ordinary Muslim citizens in Macedonia and official state-sanctioned representatives of the IRCM towards the refugee crisis, combining archival research and documentary analysis of EU bordering reports and policy action plans with insights gained from 20 informal interviews conducted between June and August 2015. Illuminating the anxieties of a borderland Muslim community in close contact with refugees, the interviews provide a more nuanced account of the intersection of local, national and transnational politics that juxtapose local Balkan Muslims with foreign migrant Muslims, and were crucial in suggesting inconsistencies within the official discourse on the Balkan vs. Arab Islam.

Research with bordering communities, especially (post) Yugoslav Muslim communities, comes with several limitations. Prolonged and continuous surveillance under Socialist Yugoslavia combined with recent histories of wars and violence have created fears of speaking openly. The ruling of the Macedonian government to criminalize assistance to refugees (Georgiev 2016, 363) and the media disclosure of pervasive wiretapping of citizens since 2012 (Besimi and Prelec 2015) have perpetuated these fears exponentially. Given that very few members of the community were comfortable speaking about their position vis-à-vis the criminalization of refugee assistance and the handling of the refugee crisis, the goal of this paper is to unearth the factors that inform these fears and illuminate the context in which they are produced. The limited number of interviews conducted and recorded on the condition of anonymity may serve more towards the opening of a debate on the subject rather than drawing any definite conclusions. 
In the first part, I set out the conceptual framework for my analysis, focusing on political geographies and bordering. Engaging with critical border literature, I look at the mobilization of racial and religious categories in the materialization of EU borders in the Balkans. The second part examines the EU surveillance and security architecture, from its policy perception of Muslim communities in the Balkans as a weak link to the effect that these policies have on the ground through their enactment by state and local authorities. The final part presents an analysis based on a combination of semi-structured interviews with persons directly involved as well as personal observations concerning the presence and impact of Muslim self-surveillance in the Macedonian borderland.

\section{Borders and "Balkan Islam"}

Between 2014 and 2016, reports emerged concerning Bulgarian vigilantes patrolling the borders of the EU. European far-right activists came to their support by giving them visibility as the "defenders of Europe". A few became YouTube sensations, like Dinko "The Destroyer", Valev, the organizer of the first paramilitary migrant hunting patrols along the Bulgarian-Turkish border, and Petar Nizamov, who gathered vigilantes into a Civil Squad for the Protection of Women and Faith. A more interesting hero, however, was a Bulgarian Muslim interviewed by former British National Party and Britain First member James Dowson, currently President of the European Christian Family Forum. Accused of racism and Islamophobia, Dowson claims that his paramilitary migrant patrol includes several Bulgarian Muslims, asking one alleged member to face the camera and explain his rationale. "We, the Bulgarian Muslims, cannot accept jihadist and islamists, people who violate our culture; we are used to living by European standards and by Bulgarian standards", says the man, "we want to stop an Islamic invasion". As Dowson interjects with praise for being an "integral part of the patrol", the Bulgarian Muslim vigilante gratefully reminds Dowson that "by helping us on the Bulgarian border, you are helping yourself and Europe. We must stop them here". At the end, Dowson hugs the Bulgarian Muslim with "thank you very much my brother".

While this deployment of Balkan Muslims to secure and surveil EU borders from foreign "jihadist and Islamist" intruders is neither new nor exclusive to the far right, it is interesting to note how local Muslims are engaged to curtail the critique of racism and Islamophobia embedded in the EU border regimes. The recent production of Muslims in the Balkans as culturally, historically and spatially European has gone hand-in-hand with a deluge of EU border strengthening policies. This convergence shifts attention from the narrow perception of borders as ratified physical nation-state boundaries to the discursive and moral percepts that facilitate the securitization of 
borders, forming, as Albahari $(2006,28)$ notes, "a broad continuum of contextual and shifting meanings, practices, and engagements".

Recent scholarship on borders demonstrates how "mobility control regimes use difference to constitute different spatial practices" (Burridge et al. 2017, 241), turning borders into "powerful tools of segmentation and differentiation" (244). Ehrkamp and Nagel (2017), for instance, show how "differential inclusion" of Latina/o migrants in white faith-based communities in the southern US reproduce legitimate and illegitimate positions beyond the physical border. This differentiation, however, is not always straightforward, stable or binary but rather operates, as Puar $(2007,175)$ suggests, through "a constant sliding between that which can be disciplined and that which must be outlawed". This is particularly visible in projects of "integration" of Muslims in the EU and the US, where the racialization of religious difference operates through the constitution of "good" and "bad" Muslims that conditions the inclusion of one group on their ability to exclude the Other (Mamdani 2004; see also Asad 2006; Bowen 2007; Scott 2007). Debates on the Balkan EU borders employ similar differences by pitting "European" and "secular" Muslims against the migrant and Middle Eastern Other. This proof of loyalty to Europe has to be continuously corroborated by those within and outside the EU perceived as non-European (El-Tayeb 2011).

Both critical race and border scholarship however focus mainly on cases within the EU and the US, leaving liminal border spaces, such as the Balkans, underexplored. Studies on the external management of borders also tend to overlook the Balkans, prioritizing North Africa and the Mediterranean basin, the spaces in which EU shifts border responsibilities to third countries through various "neighbourhood" and "partnership" policies through financial incentives (Albahari 2006; Walters 2009, 2015; Van Houtum 2010; Rumford 2011; Scott 2016; Burridge et al. 2017; Vives 2017).

In the Balkans, as Bialasiewicz (2012, 846ff) points out, EU direct involvement in state-building with both military and/or civilian missions has given paramount attention to the question of border management, turning countries like Bosnia-Herzegovina, Kosovo or Macedonia into "Europe's policemen". Indeed, the promise of "eventual EU membership", is acknowledged as the "most powerful policy tool" serving the "EU's strategic interests in stability, security, and conflict prevention" (Commission of the European Communities 2008, 2). Deploying EU membership as an inventive for states along the Balkan Route (see Figure 1) however is neither a straightforward nor a state-sanctioned, top-down process. The Balkan Route constitutes a major geopolitical corridor of transitional and transient sites of migrant mobility with multiple actors ranging from EU and state-based containment and controls (such as the EU-Turkey deal) to ordinary people enacting or contesting the borders along the route. 


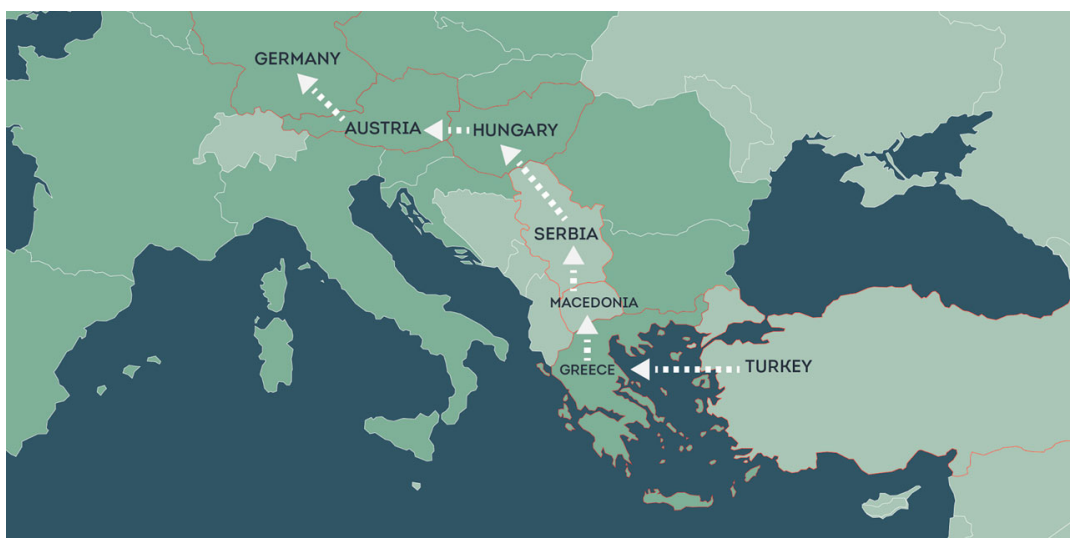

Figure 1. AJ+/Skyler Rodriguez in Alfred, Zachary and Nikolov, Nikolay "Europe's 'NoMan's Land' A refugee's guide through the Western Balkans" AJ+. [https://medium. com/@ajplus/europe-s-no-man-s-land-7f6c1f3c3057, accessed December 27, 2017]

Recent efforts to theorize the complexity of borders beyond the onedimensional state-centred power and territoriality call for a more "polymorphic" approach to study border control as a way of capturing the multilevel governance of borders (Jessop 2016), an approach that "recognizes the complexity and the inter-connections between borders, territory, spatial politics and governance" (Burridge et al. 2017, 245). The polymorphic approach has been important both in "identifying forms and modalities of resistance" and to grasp ordinary everyday practices in "places where most people live their lives" (Jessop 2016, 3). Borders in this line of thinking are not only sites of security and surveillance or spaces of humanitarian confinement (Makaremi 2009, 430f) but can also be conceptualized as "mobile commons" (Trimikliniotis, Parsanoglou, and Tsianos 2014). The concept of mobile commons allows us to attend to the everyday politics along refugee routes in line with Aradau and Huysmans (2014), and Nyers (2012, 2015), by engaging with the ways in which people who travel through and/or live around borders negotiate, contest and/or evade them and in the process, constitute themselves as new transregional political subjects.

Attending to the everyday enactment and contestation of borders can offset the "managerial" and standardized EU technocratic language that conceals the racial, religious and ethnic tensions inherent in the EU bordermaking processes. While public debates on the Syrian "refugee crisis" are fraught with racist and Islamophobic language, the discursive dimensions of "othering" are hidden through the "colour-blind" decision-making language of EU border bureaucracies. These understated or "hidden borders" as Mountz calls them $(2011,66)$ are important as this is where "classed and racialized struggles over entry, exclusion, citizenship and belonging" are fought over and racialized discourses narrating exclusion are generated. 
Research centres, think tanks and academic conferences and publications have responded to and perpetuated the EU geopolitical categorization of Muslims in the Balkans as autochthonous "European", by designing studies and policies that configure Balkan Islam as an authentic "European" Islam, frequently in contrast to migrant, but particularly Arab, Islam (see, Bougarel 2005; Dittrich and Montanaro-Jankovski 2005; Vickers 2008; Ghamin 2010; Arbutina 2011; Merdjanova 2013; Cimbalo 2014; Lederer 2015). A political, policy and academic project, "Balkan Islam" loosely binds together diverse Muslim populations in Europe that are deemed vulnerable to succumbing to the dangers of an external radical Arab Islam. The EU-directed surveillance imperative has put government-sponsored Muslim community organizations like the IRCM under pressure to police their communities but it has also empowered them to capitalize on their newfound counter-radicalization role to solidify their slippery authority.

Frequently referenced as "multiculturalism", the peculiar (neo)liberal European governance of Muslims inside the EU has come to the attention of several scholars (Amir-Moazami 2011; Bracke 2011; Yılmaz 2011), but few have questioned the reverberations of this kind of politics on the fringes of the EU, where post-Socialist Muslim majority countries, such as Albania, Bosnia-Herzegovina and Kosovo, as well as Macedonia, Serbia and Montenegro with sizable Muslim minorities, are cordoned off as Europeans in the making and waitlisted to join the union.

The process of recovering post-cold war European-ness is not limited to Muslim subjects only. All post-socialist societies in the region have been subjected to pressure to rectify their "misalignment" from Europe, but before they can be integrated, they must be first produced as, and pass, for Europeans. Balkan states with Muslim populations, often post-Ottoman, post-Socialist and post-conflict, considerably complicate the "unification" of European borders, in which a new "Iron Curtain should divide Europe from, and insulate it against, the Islamic Other" (Morley and Robins 1995, 190). Recent decolonial queer and trans interventions in border studies have noted how the dismissal of the West/East division as outdated after the fall of the Berlin Wall in 1989 has escalated the employment of the Occident/Orient division, turning former Eastern Europe into "a buffer zone to control and block migrations from Africa and Asia, while migrants from former Eastern countries are at the same time subjected to control, discrimination (employment), and processes of deportation from the former Western Europe" (Kancler 2017, emphasis in the original).

The production of EU borders in Balkans thus generates a specific kind of border politics of "self" and "other", based in part on the increased racialization of religious difference that pits Balkan Muslims as secular, white and autochthonous Europeans, against the more darker and thus more fanatical migrant Middle Eastern Muslims (Rexhepi 2017, 60). It is important 
to note that the efforts to incorporate Balkan Muslims into the EU do not entirely project their racialized suspect marker onto the new racialized migrant Muslim other. Rather, racialized modalities of exclusion are continuously shifted. Although populations labelled as "Muslims" do not meet the unspoken but seemingly essential criteria of European "normalized, Christian(ized, secular) whiteness" noted by El-Tayeb (2016), ongoing migrant movements propel Muslims in the Balkans as potentially recoverable Europeans.

Scholars often attribute secular and moderate practices to "Balkan Islam", which may interchangeably pass for Albanian, Bosnian or Bulgarian Islam. These seemingly stable categories have proven porous, particularly since Muslim practices are not usually defined by geographic boundaries, but rather by theological constellations. Even from a geopolitical perspective, separating Balkan Islam from Middle Eastern Islam seems arbitrary given the transregional religious networks (Henig 2016), ranging from the Greek Muslims in Syria and Lebanon (Lasithiotaki 2015) to the Herzegovinian Muslim Colony in Caesarea, Palestine (Li and Seferović 2015), to the Albanian Muslim community of Damascus (Gera 2012). Reconciling academic knowledge production on "Balkan Islam" with my research and personal experience has proved difficult, not only because the very idea of a Balkan-wide Islam has the tendency to homogenize a multitude of diverse practices and communities but also because it turns a blind eye to the ongoing ties of Muslims in the Balkans with Muslims from the Middle East and beyond.

Local critics have frequently addressed the problematic cultural and theoretical presuppositions of the Balkan Islam discourse. For the Bosnian Islamic scholar Karčić $(2010,1)$, although this typology may be useful for framing micro-scale sociological analyses of Islam, it is limited for understanding geographical typologies "as a way of expressing normative religious teachings". "European Islam", argues Karčić, "cannot mean a special type of Islam [...] nevertheless, it is possible that someone is wishing for some special type of Islam". Furthering Karčić's critique, one may ask who wishes for this "special type of Islam" and who benefits from a discourse that produces a spatially specific "Balkan Islam"? How are these categories employed in the materialization and governance of borders, both moral and political, that seek to sediment stable differences of otherwise porous boundaries between local and migrant Muslims? What are the ultimate effects of this discourse on local Muslim communities and institutions?

\section{Security and surveillance assemblages along the Balkan Route}

Reporting to the European Parliament on the links between organized crime and terrorism, the EU's Directorate-General for Internal Policies addressed 
concerns about the spread of radical Islam from the Middle East into the Balkans, emphasizing that "as these developments unfold and countries like Serbia, Montenegro, and FYROM move towards greater E.U. incorporation, the ease with which OC [organized crime] networks can operate in Europe will only increase" (Directorate-General for Internal Policies 2012, 18-19).

Linking these concerns with "third-generation Balkan diaspora youth becoming involved in radical Islamism" within Europe, the report notes that since

the previous generation were involved in criminality, law enforcement officers in some European states have expressed their concerns over the potential for natural ties to develop between family/community members with both criminal connections and those who have adopted a militant Islamist agenda [emphasis added]. (Directorate-General for Internal Policies 2012, 439)

The tropes of Balkan criminality and illegal human trafficking have served to underwrite calls for stricter mobility regulations and intensified border control in the past; the fear of radical Islam spreading through the Balkans has further expanded these tropes (Rexhepi 2015). The identification of Balkan Muslims with criminality and radical Islam and the fear of their convergence with transient refugees through the Balkan Route seem to have reignited the myth of the "green transversal". Used repeatedly in the 1990s during the wars in Bosnia and Kosovo by the Yugoslav government, in the "green transversal" analogy, Balkan Muslims are paralleled with an Islamic Trojan horse, linking Islamist cells in the Middle East with those in Europe via the Balkans (Karčić 2017). According to this scenario, Muslims living in the Balkans as well as second- and third-generation Balkan Muslims, EU citizens, are conceived as the weak link of Fortress Europe; their contact with refugees is deemed a priori a security threat. Urging EU parliamentarians to strengthen the physical and political EU-Balkan borders to prevent illegal migration from the Middle East for fear of the spread of radical Islamic ideologies, the report resumes that "this is a potential development that needs to be closely watched" (Directorate-General for Internal Policies 2012, 25).

With the Balkans perceived as a zone of vulnerability requiring constant surveillance, the refugee route came under intense scrutiny between 2014 and 2016. Dimitris Avramopoulos, European Commissioner for Migration, Home Affairs and Citizenship, announced the deployment of Europol, "in the Western Balkan region to strengthen the cooperation and information exchange on migrant smuggling and counter-terrorism investigations and activities" (Avramopoulos 2016). Chief among investigative initiatives, the EU Western Balkan Counter-Terrorism Initiative, an umbrella framework established by the Council of the European Union in 2015, connects various regional security institutions to monitor, manage and prevent the convergence of migration, terrorism and organized criminal networks (Council for 
the European Union 2015a). Through this initiative, countries of the region are called to "permanent vigilance" to secure the regions borders from "unprecedented scale of migrant smuggling by the criminal networks" ensuring that the cooperation would result in "effective border management and fighting migrant smuggling" as "top priorities for both the EU and the Western Balkans" (Council of the European Union 2017). In 2017, with the proposal of the EU, the Western Balkans Counter-Terrorism initiative was expanded "to cover also the fight against serious and organised crime and border security" to "efficiently and effectively address counter-terrorism and radicalisation, but also transnational organised crime and border security, in line with the new Integrative Internal Security Governance model and in cooperation with the relevant EU agencies" (Council of the European Union 2017).

A 2016 report published by Regional Cooperation Council, a member of the initiative, discusses the Arab presence in Bosnia-Herzegovina as a security problem, raising concerns over the "increases in investment and tourism relationships with investors of conservative styles of faith and dress (particularly from the Gulf states) [that] have recently increased visible signs of the new conservative Islam in many communities" (Regional Cooperation Council 2016, 27). The report recommends that the EU and local governments should "support scholarship programs aimed at confirming to questioning Muslims that democracy and liberalism do work for them, and that democracy, constitutional liberalism and Islam are compatible [emphasis added]" (Regional Cooperation Council 2016, 33).

The EU discourse projects Muslim populations in the Balkans as secular, peaceful and moderate, only to have this alleged secularism doubly assaulted by new radical ideologies from the Middle East and by organized crime and terrorist networks alike. This problem-solution imperative calls simultaneously for the strengthening of borders to combat organized crime and terrorism while drawing an ideological boundary between "Balkan Islam" and other Islams who seek to destabilize it. Within these larger security and surveillance assemblages, the Syrian refugee is perceived as a vulnerability source, a double transgressor of normative, material borders, as well as racial and religious ones.

Western Balkan states have responded to the pressure of performing loyalty to Europe with sweeping measures, from arrests and trials of "radical" Muslims to new legal provisions that have supplanted previous counter-terrorist and counter-radicalization measures. The Albanian National Strategy for Development and Integration (2015), the Kosovo Strategy for Counter-Terrorism (2015) and the Macedonian National Strategy for Fighting Terrorism (2016) have all established national coordinators who feed domestic information and intelligence to various EU security and border agencies. These legislative and policing strategies, while not officially singling out Muslim communities, target them almost exclusively, as exemplified by the 
counter-terrorist raids in Albania (Jazexhi 2017), Bulgaria (Nikolova 2016) and Kosovo (Rexhepi 2015). Local Muslim communities have frequently interpreted these raids as an attempt by their governments to assuage the EU pressure rather than structurally tackle the factors contributing to violent extremism (Stojkovski and Selimi 2016, 62).

The EU Western Balkans Counter Terrorism Initiative has also tasked the Western Balkan countries with looking for signs of radicalization while "promot[ing] Islam together with European values" including the involvement of religious dignitaries (Council of the European Union 2015b, 5). The signatories have also agreed to an integrated security governance to collect, coordinate and share information with the EU such as Europol and Frontex, to confront the "possible connections between illegal migration and terrorism" (Council of the European Union 2015b, 7). Passing on the task of monitoring to the involved communities themselves, the governments of Bosnia-Herzegovina, Macedonia, Kosovo, Albania and Bulgaria have frequently pressured official Islamic institutions to report on suspected agitators and to observe the relationships of Muslim activists with refugees, as well as Middle Eastern organizations and people. In some instances, including Albania, Bosnia-Herzegovina and Macedonia, the state-sanctioned Islamic institutions have seized the opportunity to deal with "dissident" congregations who refuse to come under their authority by labelling them as radicals. In August 2015, for instance, after the IRCM denounced Jahja Pasha and Tutunsëz mosques in Skopje to be preaching a radical and foreign interpretation of Islam, the Macedonian security forces raided the mosques, arresting several imams and community members under charges of terrorism and collusion with ISIS (Marusic 2015).

Responding to the demands of the EU Western Balkans Counter Terrorism Initiative, Muslim institutions and community leaders have engaged in counter-radicalization programmes with the purpose of differentiating and classifying good, local and "autochthonous" Islamic practices from foreign and radical interpretations of Islam. In Macedonia, one of the key institutions in streamlining this classification is the official IRCM. Established in 1991, the IRCM is recognized by the state as the sole legitimate representative body of all Muslims living in Macedonia (Idriz and Ali 2015). Like all post-Yugoslav state-sanctioned Islamic Communities, the IRCM too is a descendant of the Islamic Community of the Socialist Federal Republic of Yugoslavia (ICSFRY). Established in 1947, ICSFRY was based in Sarajevo with four constitutive councils, the Islamic Community of Bosnia and Herzegovina, Croatia and Slovenia, the Islamic Community of Serbia, the Islamic Community of Macedonia and the Islamic Community of Montenegro (Idriz and Ali 2015, 85-86). The institution was frequently criticized for operating under the directives of the Yugoslav Communist Party. Although Yugoslavia's split from the Soviet orbit and its subsequent participation in 
establishing the Non-Aligned Movement in 1956 relaxed the previously repressive measures on Muslim communities, the federation continued to closely monitor ICSFRY's activities (Miller 2014). Critics argue that the Yugoslav state used the ICSFRY to expand its political ambitions within the NonAligned Movement, where most founding members were Muslim majority countries, while continuing its widespread discriminatory practices towards Muslims at home (Rexhepi 2017). After the disintegration of Yugoslavia, all former republics established their own state-sanctioned Islamic religious communities based on similar structures governing Muslim communities in Yugoslavia (Fazlic 2012).

With headquarters in Skopje and administrative units across Macedonia, the IRCM appoints imams and manages mosques and waqfs. In 2015, the IRCM established its own majlis (decision-making council) that can issue fatwas on the distinction between proper and improper interpretations of Islam. Making the IRCM the sole religious institution recognized by the state has led to an unusual centralization of power in the hands of IRCM. During socialist Yugoslavia and up until recently, Muslim communities were allowed to opt out of responding to the authority of IRCM. Such dissent was neither radical nor was it seen as a refusal, but merely as a choice communities made themselves. The recent rise of Muslim community-based organizations and initiatives, centres and independent mosques has in part been in response to the centralizing tendencies of IRCM in homogenizing and closely regulating religious practices. Religious communities and individuals that do not practice the IRCM sanctioned Hanafi Sunni Islam have increasingly come under pressure and are labelled as foreign practices incompatible with the Macedonian "moderate" Islam. Since 2014, all imams employed by the IRCM are obliged to sign a declaration pledging that in their practice, they will maintain the Hanafi teachings and when dissenting from this interpretation of "autochthonous and traditional Islam, the IRCM has the right to remove such imams" (Ramadani 2014). More recently, the IRCM has developed a counter-radicalization project with the aim of "empowering and giving public visibility to moderate voices in the community" as a means of confronting radical and misinterpreted teachings of Islam (Stojkovski and Selimi 2016, 29). This project has gone hand in hand with IRCM's increasing monopolization of almost all Muslim religious ceremonies in Macedonia, including the Hajj.

Widespread tensions between the IRCM and Muslim communities have resulted in attempts by various Muslim communities and individual imams to either seek independence from the legal framework of the IRCM or to attempt to overthrow the current administration headed by Sulejman Rexhepi. In summer 2010, for instance, several mosques and imams in the capital Skopje refused access to the IRCM-appointed imams. In turn, the IRCM called upon the state security services to remove the "foreign-inspired 
religious groups" claiming that the "Wahabist structures act against the Constitution of the Islamic Community, the rules of procedure and hierarchy" (Jovanovska and Gjorgeski 2010). Most of the insubordinate imams were fired and replaced by IRCM-appointed imams. The tensions resurfaced again in 2015. On 4 April 2015, the mufti of Skopje Ibrahim Shabani, a former secretary general of the IRCM, seized the IRCM headquarters for 10 days. He demanded the removal of the current head Sulejman Rexhepi and called for new elections and investigation of various corruption charges levied against Rexhepi. In his frequent critique of the head of IRCM, Shabani suggested that the IRCM continues to reproduce socialist Yugoslav logic as an institution largely serving the interests of the Macedonian state and no longer those of the Muslim communities. These accusations were levied at a time when the Macedonian state was subjected to national and international critique for its ill treatment of refugees as well as for frequently using the threat of "radical Islam" to justify repressive measures against the Albanian minority. Several months after the violent clashes in the town of Kumanovo between state security forces and local citizens that left 18 people dead (Dimovski 2016), the causes of which still remain obscure, the Macedonian security forces raided Muslim community organizations and mosques suggesting a link between the clashes and radical Islamist groups recruiting citizens to fight for ISIS (Marusic 2015).

In 2015, these tensions were further complicated by increased attacks, both physical and verbal on local and migrant Muslim communities (Georgiev 2016). Defending itself against mounting accusations of using violence on refugees, the Macedonian government criminalized contact between citizens and migrants arguing that a combination of radical Islamic circles and refugee crisis were destabilizing the country (Pajaziti 2015). Similarly, Sulejman Rexhepi, IRCM's head, called for the close monitoring of migrants coming from Syria and other "crisis ridden countries in the Middle East" as they could cause further instability (Jajaga 2016).

The handling of the refugee crisis by independent Muslim communitybased organizations, despite the warnings issued by the IRCM, has further exposed the institution to critique, although the relationships remain complicated. Some humanitarian organizations like the Association Veli \& Arif from Kumanovo, who have been involved in providing humanitarian assistance to migrants, have kept a distance from IRCM and have sided with Ibrahim Shabani as he attempted to overthrow the current IRCM administration. Other faith-based communities have opted for collaboration.

\section{"How were refugees from Kosovo our brothers and sisters but the refugees from Syria are not?"}

Muslims constitute thirty-three per cent of Macedonia's population of two million. In the summer of 2015, approximately 50,000 predominantly 
Muslim Arab refugees from Syria passed through the country travelling north to Europe. As mentioned in the Introduction, the response to this crisis by the official IRCM was minimal. IRCM's primary concern was not organizing help for the refugees, but how to distance itself from them to protect local Muslims from the threat of political Islamist ideology.

While the dominant understanding of Balkan Islam as secular and European - and therefore different from other Islams - is still persistent among the leading imams of the IRCM, there is an increasingly visible opposition to this debate from both the leadership ranks and from the community.

One of my interviewees, Rejhan, who works for the IRCM, pointed out how "besides a few opportunities to photographically document humanitarian relief efforts to ease the pressure of the jamaat (congregation), the IRCM leadership has distanced itself from the refugees for fear of refugees interacting with, and potentially, radicalizing our local Muslims". IRCM's decision to distance itself from refugees, Islamic humanitarian organizations and the jamaat, who were keen on raising awareness and organize support for the refugees, had produced palpable tensions for Muslim communities caught in between.

Most refugees had chosen to cross the border from Greece to Macedonia at Gevgelija. But the constant opening and closing of the border had forced some refugees to seek alternative crossings into Macedonia. A few walked west to Bitola. The Muslim population in Bitola and nearby Prespa had pressured the local IRCM to organize a humanitarian relief effort and demanded that the local government prevent police violence on refugees. In the local mosque in the nearby town of Resen, the call for assistance to refugees by the jamaat had been met with caution by the IRCM. Warnings to disassociate from the refugees had thrown the community members and the institutional representatives into a conflict.

In the following months, from May to August 2015, I interviewed various members of the mosque, including the imam and administrative officials on the refugee question, the fear of ISIS recruiters, Islamic charities, radicalization and state surveillance of religious activities.

The conflation of refugees with jihadists by local and international media, and the increased surveillance of the Muslim communities through counterterrorist security measures to prevent Balkan Muslims from joining ISIS, had created an atmosphere of fear and distrust. Interaction with refugees was considered a threat that could bring unwanted attention to the Muslim communities, particularly since in Macedonia the government had frequently utilized the war on terror language to promote EU and NATO integration as a solution to radicalization. Consider the statement by the Macedonian President Ivanov at the UN General Assembly in 2015: "Without integration of the Republic of Macedonia and other Western Balkan countries in Europe, there is a vacuum in the geopolitical space. Let us not allow the vacuum to be filled with 
radicalism, religious fundamentalism and uncertainty." Warning of the establishment of a Balkan Caliphate, Ivanov argued, "there is no more time or excuses to block European and Euro-Atlantic integration and initiatives. Our region is vulnerable" (Marusic 2014).

The local authorities in Bitola and Prespa had echoed the concerns of the central government of refugees posing security concerns. These views came to clash with those of some of the local Muslim population in Prespa, who wanted to make their mosque available for refugees. Skender, the initiator of a proposal to open the doors of the mosque in Resen for refugees, explained that "the imam and the administration refused the request claiming that it was not clear who the refugees were, questioning whether there were radicals among them who could compromise the traditional practices of moderate and tolerant Islam". Community members countered that this was an unfounded fear, part of larger Islamophobic concerns circulating in the media to justify the closing of borders and the heightened surveillance of Islamic institutions by state security. Skender also pointed out the deeply impacted internal dynamics of the community:

There are several problems with how the refugee crisis is presented in the media and politics. The assumption is that there could be terrorists among the refugees simply because they are coming from the Middle East and that we need to stay away from them. What the refugee crisis has shown is something that we have known all along, that the IRCM's fear of radicalization has made the community fearful of outsiders.

Skender noted the intense social pressure preceding the refugee crisis to ignore Muslim politics outside the Balkans, the fear being that such engagement would create greater government suspicion and surveillance:

Even before the refugee crisis, we were under constant pressure to limit our attention to our own jamaat. We were routinely discouraged to bring up the issues of Palestine or Syria for fear of coming under more suspicion as I am sure we are already surveilled regularly by the state.

On 28 July 2015, I interviewed Emel, who had already organized several initiatives to collect food and clothing for refugees and was disappointed with the response in Macedonia towards the refugees. She pointed out how "every time you hear about the refugees you hear that they are Muslim, why should this matter at all? I am sure there are non-Muslims among refugees and people who don't identify with any religion at all". Recalling the Kosovar refugee crisis in summer 1999, how they had opened their homes for Kosovar refugees, as opposed to refugees from Syria, she asked, "How were refugees from Kosovo our brothers and sisters but the refugees from Syria are not?" 
A few days later I talked to the local imam about the tensions. He felt that securitization measures were justified because of an imminent threat to the local Islam:

The mosque serves the needs of the community and the community alone; we are far from Syria and Iraq and you have seen on the news what happens to those too interested in the issues there. They end up in ISIS or in prison.

The imam went on to cite the threat of radicalization from Arab Muslims: "The attempt by radicalized members of our community to take over the IRCM earlier this year, is nothing less and nothing more than the result of people being indoctrinated by foreign organizations and people from the Arab world." The imam was referring to the events of April-May 2015, when following clashes between Sulejman Rexhepi's "moderate" wing and Ibrahim Shabani's "radical" wing, people associated with the latter had tried to take over the administrative headquarters of IRCM.

While many in the jamaat shared the imam's view, there seemed to be some weakening of the dominant narrative of a European, local Islam versus a foreign Middle East incarnation. In an interview with Rejhan, an employee of the IRCM, he raised criticism that has emerged of this view and the IRCM in the community:

The tension is presented as two extreme opposites and it usually justifies the suspicion with which people who are trained or just travel to the Middle East are viewed by the more secular wing. The secular wing has been frequently accused of bringing IRCM too close to Albanian political parties who are coalition partners in the current government. For them, a watered down Islam is in the best interest of Macedonia's future in the EU and for the positionality of Muslims within Macedonia ... It is a shame that this conflict has turned IRCM's suspicious towards the refugee crisis, alienating some members of the community.

In late August, the Macedonian government deployed an antiterror force to close its borders with Greece and prevent further entry of refugees. The fear of radicalization and terrorists disguised as refugees had become a salient issue. In the Balkans, the border zone of an expanding Europe, all anxieties concerning Islam, the Middle East and terror are magnified for EU policy-makers. The consequence is an extensive surveillance regime, including self-policing by Muslim communities, and a Muslim appropriation of the anxiety of infiltration. Yet, the physical border crossing is just a small part of this political geographic crisis. Its closure cannot resolve the sense of crisis that lies at the heart of the very idea of a "Balkan Islam".

\section{Conclusion}

Expanding scholarship on borders, this article shifted attention away from the narrow perception of borders as ratified physical boundaries to the protracted 
practices that produce mobility control regimes in the European borderlands of the Balkans. It shows how the politics of EU cooperation in the securitization of borders in a post-Socialist and post-conflict space create multiple tensions on different scales: states in the EU periphery, such as Macedonia, have to assert their European-ness by mobilizing the war on terror language to further their agendas of EU membership and NATO integration at the expense of their local and migrant Muslim communities. State-sanctioned Islamic institutions tasked with calling upon Muslim communities to distance themselves from Syrian refugees not only reproduce the racialization of migrants; the centralization of power in the hands of the IRCM creates deep rifts within the Muslim community perpetuating an atmosphere of fear and distrust. EU directives of surveillance hinder the IRCM's own ability to fully negotiate the terms of belonging as a religious community within the Macedonian nation-state.

I have also explored the complexities of bordering processes with a bottom-up approach, illustrating how ordinary Muslim citizens question the politics of racializing religious difference and refuse to see Middle Eastern migrants as the other. Although the lack of studies and the difficulty of carrying out research along the EU border warrants against any conclusive remarks, this article has attempted to open up new ways of approaching the EU's expansion of borders in the Balkans beyond the standard narratives that justify and legitimize it in the name of securitization. Further studies of how these processes affect local communities and how kinship, political and religious ties operate across geopolitical divides are needed to better understand the everyday impact these borders have on the communities who embody and are embedded in them.

\section{Disclosure statement}

No potential conflict of interest was reported by the author.

\section{References}

Albahari, Maurizio. 2006. Death and the Moral State: Making Borders and Sovereignty at the Southern Edges of Europe. San Diego: Center for Comparative Immigration Studies, University of California.

Alfred, Zachary, and Nikolay Nikolov. 2015. “Europe's 'No-Man's Land' A refugee's Guide Through the Western Balkans." AJ+. Accessed 21 December 2017. https://medium. com/@ajplus/europe-s-no-man-s-land-7f6c1f3c3057.

Amir-Moazami, Schirin. 2011. "Dialogue as a Governmental Technique: Managing Gendered Islam in Germany." Feminist Review 98: 9-27.

Aradau, C., and J. Huysmans. 2014. "Critical Methods in International Relations: The Politics of Tools, Devices and Acts." European Journal of International Relations 20 (3): 596-619.

Arbutina, Zoran. 2011. "Bosnian Islam: A Model for Integration?" Deutsche Welle, November 25. http://www.dw.de/bosnian-islam-a-model-for-integration/a15553768. 
Asad, Talal. 2006. "Trying to Understand French Secularism." In Political Theologies: Public Religions in a Post-Secular World, edited by Hent de Vries, and Lawrence E. Sullivan, 494-526. New York: Fordham University Press.

Avramopoulos, Dimitris. 2016. "The Western Balkans and their European Path." December 16. http://www.delmne.ec.europa.eu/code/navigate.php?ld=3770.

Besimi, Fatmir, and Tena Prelec. 2015. “Five Minutes with Fatmir Besimi: 'Macedonia's Wire-tapping Scandal is Taking the Country in the Opposite Direction of Where It Needs to Go'." LSE European Politics and Policy (EUROPP) Blog.

Bialasiewicz, L. 2012. "Off-shoring and Out-sourcing the Borders of Europe: Libya and EU Border Work in the Mediterranean." Geopolitics 17 (4): 843-866.

Bougarel, Xavier. 2005. "The Role of Balkan Muslims in Building a European Islam." European Policy Center. Accessed November 23. http://www.epc.eu/documents/ uploads/81451702_EPC\%20lssue\%20Paper\%2043\%20lslam\%20in\%20the\% 20Balkans.pdf.

Bowen, John. 2007. Why the French Don't Like Headscarves: Islam, the State, and Public Space. Princeton, NJ: Princeton University Press.

Bracke, Sarah. 2011. "Subjects of Debate: Secular and Sexual Exceptionalism, and Muslim Women in the Netherlands." Feminist Review 98 (1): 28-46.

Burridge, A., N. Gill, A. Kocher, and L. Martin. 2017. "Polymorphic Borders." Territory, Politics, Governance (introduction to special issue) 5 (3): 239-251.

Cimbalo, Giovanni. 2014. "L'Islam plurale in Albania: modelli di relazione con lo Stato e pace religiosa. II ruolo del diritto statale e di quello religioso." Stato, Chiese e pluralismo confessionale Rivista telematica n. 8/2014.

Commission of the European Communities. 2008. "Communication from the Commission to the Council and the European Parliament." Enlargement Strategy and Main Challenges 2008-2009. Brussels, 5.11.2008 COM (2008) 674.

Council of the European Union. 2015a. EU Western Balkan Counter-terrorism Initiative: Integrative Plan of Action. EU, Brussels, 4 December 2015 13887/15.

Council of the European Union. 2015b. Vienna Declaration - Tackling Violent Extremism and Terrorism. EU, Brussels, 25 March 2015 7500/15.

Council of the European Union. 2017. "EU - Western Balkans Justice and Home Affairs Ministerial Forum - Joint Press Statement." October 27. Accessed October 30, 2017. http://www.consilium.europa.eu/en/press/press-releases/2017/10/27/euwestern-balkans-justice-and-home-affairs-ministerial-forum-joint-press-statement/.

Dimovski, Sase. 2016. "Kumanovo Gunmen Face Trial in Macedonia." Balkan Insight. February 8. Accessed June 28, 2016. http://www.balkaninsight.com/en/article/ kumanovo-gunmen-face-trial-in-macedonia-02-08-2016-1.

Directorate-General for Internal Policies. 2012. "Europe's Crime-Terror Nexus: Links between Terrorist and Organised Crime Groups in the European Union." European Parliament. Accessed April 5, 2016. http://www.europarl.europa.eu/document/ activities/cont/201211/20121127ATT56707/20121127ATT56707EN.pdf.

Dittrich and Montanaro-Jankovski. 2005. "Introduction." In The Role of Balkan Muslims in Building a European Islam. European Policy Center. Accessed November 23, 2005. http://www.epc.eu/documents/uploads/81451702_EPC\%20lssue\%20Paper\%2043\% 20lslam\%20in\%20the\%20Balkans.pdf.

Ehrkamp, P., and C. Nagel. 2017. "Policing the Borders of Church and Societal Membership: Immigration and Faith-based Communities in the U.S. South." Territory, Politics, Governance 5 (3: Polymorphic Borders): 318-331.

El-Tayeb, Fatima. 2011. European Others: Queering Ethnicity in Postnational Europe. Minneapolis, MN: University of Minnesota Press. 
El-Tayeb, Fatima. 2016. "Creolizing Europe." Manifesta Journal 17. http://www. manifestajournal.org/issues/creolizing-europe-0\#.

Fazlic, Hazim. 2012. "Islam in the Successor States of Former Yugoslavia-Religious Changes in the Post-Communist Balkans From 1989-2009." PhD thesis, University of Birmingham.

Georgiev, Mitre. 2016. "Macedonia." In European Islamophobia Report 2015, edited by Enes Bayraklı, and Farid Hafez, 355-373. Istanbul: SETA.

Gera, Suela. 2012. "Shqiptarët në Siri: Asad po na vret, na shkatërroi shtëpitë." Shqiptarja, August 15. Accessed May 17, 2017. http://shqiptarja.com/home/1/ shqiptaret-ne-siri-asad-po-na-vret-na-shkaterroi-shtepite-111893.html\#sthash. 7W9In8tq.hL7eJU7e.dpuf.

Ghamin, Julia. 2010. "Bosnian Umbrella Organisation Becomes New Member of German Islam Conference." Deutsche Islam Konferenz (German Islamic Conference), May 17. Accessed April 5, 2016. http://www.deutsche-islamkonferenz.de/DIK/EN/DIK/UeberDIK/Teilnehmer/Bosniaken/bosniaken-node.html.

Henig, David. 2016. "Crossing the Bosphorus: Connected Histories of 'Other' Muslims in the Post-Imperial Borderlands of Southeast Europe." Comparative Studies in Society and History 58 (4): 908-934.

Idriz, Mesut, and Muhamed Ali. 2015. "The Office of Islamic Religious Community of Macedonia: A Study from the Socio-legal Framework." Inquiry-Sarajevo Journal of Social Science 1 (2): 113-131.

Jajaga, Zërijeta H. 2016. "Rexhepi: Institucionet s'bashkëpunojnë me BFI-në, kundër radikalizmit." Eadio Evropa e Lirë. January 31, 2016. https://www.evropaelire.org/a/ 27521969.html.

Jazexhi, Olsi. 2017. "Albania." In Yearbook of Muslims in Europe. Vol. 8., edited by Oliver Scharbrodt, Samim Akgönül, Ahmet Alibai, Jørgen Nielsen, and Egdunas Racius, 1934. Leiden: Brill.

Jessop, B. 2016. "Territory, Politics, Governance and Multispatial Metagovernance." Territory, Politics, Governance 4: 8-32.

Jovanovska, Svetlana, and Branko Gjorgeski. 2010. "Radical Islam in Macedonia Worries Western Observers." July 8. https://euobserver.com/news/30446.

Kancler, Tjaša. 2017. "Body-Politics, Trans* Imaginary and Decoloniality." https://www. academia.edu/31557368/Body-politics_Trans_Imaginary_and_Decoloniality.

Karčić, Fikret. 2010. "What Is the 'Islamic Tradition of Bosniaks'?" Islamic Community in Bosnia and Herzogovina. August 17. http://www.rijaset.ba/english/index.php/ template/latest-news/222-what-is-islamic-tradition-of-bosniaks.

Karčić, Hikmet. 2017. "Uncovering the Truth: The Lake Perućac Exhumations in Eastern Bosnia." Journal of Muslim Minority Affairs, 37 (1): 114-128.

Laçi, Bekim. 2015. "Shkupi, lojë të rrezikshme me emigrantët nga Lindja: I adreson nëpër xhamitë e shqiptarëve." Accessed July 5, 2017. http://tesheshi.com/shkupiloje-te-rrezikshme-me-emigrantet-nga-lindja-i-adreson-neper-xhamite-eshqiptareve/.

Lasithiotaki, Efsevia. 2015. "The Muslim Greek Speaking Community of Syria and Lebanon: Constructions of Greek Identity in the Middle East." PhD diss., University of Exeter.

Lederer, Gyorgy. 2015. "Contemporary Islam in East Europe." NATO Academic Forum. Accessed August 28. http://www.nato.int/acad/fellow/97-99/lederer.pdf.

Li, Darryl, and Nina Seferović. 2015. "The Herzegovinian Muslim Colony in Caesarea, Palestine." Journal of Palestine Studies 45 (1): 76-83. 
Makaremi, C. 2009. "Governing Borders in France: From Extraterritorial to Humanitarian Confinement." Canadian Journal of Law and Society 24 (3): 411-432.

Mamdani, Mahmood. 2004. Good Muslim, Bad Muslim: America, the Cold War, and the Roots of Terror. New York: Random House.

Marusic, Sinisa Jakov. 2014. "Macedonia President Voices 'Balkan Caliphate' Fears." BalkanInsight, September 26. Accessed April 5, 2016. http://www.balkaninsight. com/en/article/macedonia-president-warns-on-balkan-caliphate.

Marusic, Sinisa J. 2015. "Macedonian Police Targets ISIS Suspects." Balkan Insight. N.p., August 6. Accessed June 28, 2016. http://www.balkaninsight.com/en/article/ macedonia-launches-anti-terror-busts-08-06-2015.

Merdjanova, Ina. 2013. Rediscovering the Umma: Muslims in the Balkans Between Nationalism and Transnationalism. Oxford: Oxford University Press.

Miller, Brenna. 2014. "Transnational Networks and Bosnian Muslim Identity in Tito's Yugoslavia." American Council for International Education. http:// researchfellowships.americancouncils.org/sites/researchfellowships. americancouncils.org/files/Miller_Final_Report.pdf.

Morley, David, and Kevin Robins. 1995. Spaces and Identity: Global Media, Electronic Landscapes and Cultural Boundaries. London: Routledge.

Mountz, Alison. 2011. "Border Politics: Spatial Provision and Geographical Precision." In Corey Johnson, Reece Jones, Anssi Paas, Louise Amoore, Alison Mountz, Mark Salter, Chris Rumford. "Interventions on Rethinking 'The Border' in Border Studies." Political Geography 30 (2011): 61-69.

Nikolova, Madlen Ivanova. 2016. "Islam on Trial: Normalisation of Islam in Bulgaria and the Role of Intellectuals." Diss., Central European University.

Nyers, P. 2012. "Moving Borders: The Politics of Dirt." Radical Philosophy 174: 2-6.

Nyers, P. 2015. "Migrant Citizenships and Autonomous Mobilities." Migration, Mobility, \& Displacement 1 (1): 23-39.

Pajaziti, Naser. 2015. "FYROM Fears a Wave of Refugees, the Stability of the Country is at Risk." Independent Balkan News Agency RSS. N.p., November 4. Accessed June 28, 2016. http://www.balkaneu.com/fyrom-fears-wave-refugees-stability-country-risk/.

Puar, Jasbir K. 2007. Terrorist Assemblages: Homonationalism in Queer Times. Durham, NC: Duke University Press.

Ramadani, Isak. 2014. "Intervista e Reisul Ulema, H. Sulejman ef. Rexhepi." Zëri i Amerikës (Voice of America in Albanian Language), August 16.

Regional Cooperation Council. 2016. Initiatives to Prevent/Counter Violent Extremism in South East Europe a Survey of Regional Issues, Initiatives and Opportunities. Sarajevo: Regional Cooperation Council.

Rexhepi, Piro. 2015. "Mainstreaming Islamophobia: The Politics of European Enlargement and the Balkan Crime-Terror Nexus." East European Quarterly 43 (2/3): 189-214.

Rexhepi, Piro. 2017. "Unmapping Islam in Eastern Europe: Periodization and Muslim Subjectivities in the Balkans." In Eastern Europe Unmapped: Beyond Borders and Peripheries, edited by Irene Kacandes, and Yuliya Komska, 53-77. New York: Berghahn Books.

Rumford, Chris. 2011. "Seeing Like a Border." In Corey Johnson, Reece Jones, Anssi Paas, Louise Amoore, Alison Mountz, Mark Salter, Chris Rumford. "Interventions on Rethinking 'The Border' in Border Studies." Political Geography 30 (2011): 61-69.

Scott, Joan. 2007. The Politics of the Veil. Princeton, NJ: Princeton University Press.

Scott, James Wesley, ed. 2016. EU Enlargement, Region Building and Shifting Borders of Inclusion and Exclusion. New York: Routledge. 
Stojkovski, Filip, and Kaltrina Selimi. 2016. "Assessment of Macedonia's Efforts in Countering Violent Extremism, View from Civil Society". Accessed 2 October 2017. http://www.analyticamk.org/images/Files/extremism-en-updated-FINAL-web_ ceb98.pdf

Trimikliniotis, N., D. Parsanoglou, and V. Tsianos. 2014. Mobile Commons, Migrant Digitalities and the Right to the City. Vancouver: Springer.

Van Houtum, Henk. 2010. "Human Blacklisting: The Global Apartheid of the EU's External Border Regime." Environment and Planning D: Society and Space 28 (6): 957-976.

Vickers, Miranda. 2008. Islam in Albania. Vol. 8. Swindon: Defence Academy of United Kingdom Conflict Studies Research.

Vives, Luna. 2017. "The European Union-West African Sea Border: Anti-Immigration Strategies and Territoriality." European Urban and Regional Studies 24 (2): 209-224.

Walters, William. 2009. "Europe's Borders." In The Sage Handbook of European Studies, edited by C. Rumford, 485-505. London: Sage.

Walters, William. 2015. "Reflections on Migration and Governmentality." Movements: Journal für kritische Migrations-und Grenzregimeforschung 1 (1): 1-25.

Yilmaz, Ferruh. 2011. "The Politics of the Danish Cartoon Affair: Hegemonic Intervention by the Extreme Right." Communication Studies 62 (1): 5-22. 